\title{
'n Ellips skeppingsgebeure in die Evangelieverhaal volgens Johannes
}

\author{
J A du Rand
}

(Randse Afrikaanse Universiteit)

\section{ABSTRACT}

Ellipse creation events in the Gospel story according to John

The narrative of the Fourth Gospel can be read from different viewpoints. From the perspective of the creation motif the unfolding of the story can be compared to an ellipse, emphasising two focal creation moments: the incarnation of the Logos (1:1-18) and the bestowment of the Spirit onto the disciples (20:21-23). These two creation moments are part of a literary comparison between creation and "new creation". The function of the 727 and $m$ of creation are re-enacted in the Johannine narratological lóros and $\pi \nu \in \hat{y} L a$ as part of the "new creation".

\section{ORIËNTEREND}

Die vierde Evangelieverhaal het 'n bekoorlike inkennigheid wat elke interpreteerder daarvan dwing om 'n behoorlike Johannese antenna te ontwikkel. Dit is egter nog geen waarborg dat die Johannesevangelie sy betekenis vanself en volledig beskikbaar stel nie. Dit beteken slegs dat die hoek van opvangs gedurende elke teologiese geslag verskuif word deur nuwere benaderings, metodes en hermeneutiese situasie. In hierdie geval word die antenna só geplaas dat die skeppingsmotief as hermeneutiese invalshoek onder die soeklig kom. Dit definieer slegs een moontlike perspektief of benadering omdat die Johannesevangelie hom nie laat afkamp deur enige heining van bevooroordeelde eksegetiese stelligheid nie. Die soeke na net een sogenaamde sentrale teologiese betekenis van dié Evangelieverhaal was tot nou toe onoortuigend. Matthias Rissi vat dit raak saam: "Das Buch (Johannesevangelium) als ganzes macht durchaus einen geschlossenen Eindruck und scheint einen sinnvollen Plan zu folgen. Und doch ist die Suche nach den leitenden Gesichtspunkten der Gesamtstruktur noch nicht zur Ende" (Rissi 1983:55; Du Rand 1998:5-18; Van der Watt 1991:93103). Al sou 'n enkelvoudige betekenis of struktuur nie af te dwing wees nie, word die eksegeet nogtans uitgedaag om vanuit meerdere gesigshoeke die Johannese Evangelieverhaal te interpreteer.

Om die Johannesevangelie te lees vanuit die perspektief van die skeppingsmotief, poog nie om slegs parallelle te herkonstrueer met Genesis 1 nie. Dit word in hierdie leespoging gesien binne die raamwerk van 'n ellips, by wyse van voorstelling. 'n Ellips is ' $n$ wiskundige meetkundige 
figuur wat 'n ovaalvorm behels, gevorm deur twee vaste punte. Vanuit skeppingsperspektief gesien, is die Evangelieverhaal, voorgestel as ellips, vertel met die menswording van die Seun $(1: 1-18)$ en sy blaas van die Gees oor die dissipels (20:21-23) as twee fokusmomente.

\section{2 'N SKEPPINGSVERTELLING}

Die geïmpliseerde leser in die narratief word só vertel met die oog daarop om die werklike leser teologies te beïnvloed (Darr 1993:47; Moore 1989:85-92). Dit bring ons by die moontlike affektiewe betekenis van die Johannese plot (Du Rand 1998:11-14). Die Johannese plot het te doen met die dinamiese en opeenvolgende ontvouende plan van die vertelde gebeure (Culpepper 1983:79-81; Rotz 1992). Die Johannese plot bevat veel meer as net die Jesus verhaal. Dit gaan eerder oor God se openbarende en verlossende betrokkenheid by hierdie wêreld. Die kosmiese stryd tussen lig en duisternis is ook nie meteens afgehandel in die dood en opstanding van die protagonis nie. God se konstruktiewe betrokkenheid by hierdie wêreld word voortgesit deur die dissipelsending met 'n besondere klem op die rol deur die Heilige Gees. Die teologiese klem fokus eers op die menswording en bediening van die Logos en daarna op die "van bo" geïnspireerde en geïnstigeerde dissipelsending. Die perspektief van die skeppingsgebeure verleen gesag aan die gesaghebbende optrede van die Seun, sowel as aan die dissipelsending die wêreld in. Daarom fokus 'n skeppingsperspektief opnuut op die twee Johannese vertellyne volgens die vierde Evangelie: die Jesus-bediening en die dissipelsending.

Die teologiese perspektief wat volgens die skeppingsmotief na vore tree, is dat God se betrokkenheid by sy wêreld manifesteer in die pre-eksistente Logos wat mens word en na die Vader toe terugkeer, gevolg deur die voortgang van sy bediening deur die sending van sy volgelinge (dissipels) (Culpepper 1983:88; Du Rand 1986:161-162; Tannehill 1980:57-95). Vanuit 'n skeppingsmotief gelees, kan die inhoud van die Johannesevangelie se narratief só uiteen val:

1 Aanloop (1:1-31) Die "nuwe skepping" het mens geword. Die Logos as agent van die skepping.

2 Verloop (2:1-17:26) Die "nuwe skepping" ontvou in die dade en woorde van die Seun van God as voorbereiding van die daaropvolgende dissipelsending.

3 Afloop (18:1-21:25) Die beslissende "bewys" van die "nuwe skepping" lê in die dood en opstanding van die Seun, sowel as sy skenking van die Gees aan sy dissipels.

In al drie narratiewe fases is dit opvallend dat die Johannese "sleutel" tot verstaan die "van bo" standpunt is. Dit beklemtoon die Goddelike gesagsaansprake by die "nuwe skepping"-gebeure: eers bemiddel deur die Logos 
wat mens word (1:1-18) en daaropvolgend deur die toesegging van die Gees aan die dissipels (20:21-23). Die skeppingsmotief bied die raamwerk sowel as die narratiewe drakrag van die Goddelike aktiwiteit op aarde. Die funksie daarvan is om die leser te oortuig van die Goddelike betrokkenheid by die aardse verlossingsverhaal. In albei vertellyne is Jesus die skeppingsagent: eers deur sy menswording om die "nuwe skepping" te beliggaam, en ook deur sy toesegging van die Gees aan die dissipels om die "nuwe skepping" getuigend verder te dra. Die Jesussending illustreer die ontvouing

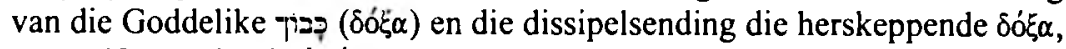
gemanifesteer in die $\dot{\alpha} \gamma \alpha \dot{\alpha} \pi \eta$, volgens die Johannese narratief.

Samevattend kan dit grafies só voorgestel word:

God se betrokkenheid in die "nuwe skepping" deur die

\begin{tabular}{|c|c|c|}
\hline Twee storielyne: & Jesussending & Dissipelsending \\
\hline $\begin{array}{l}\text { Twee fokusmomente } \\
\text { in die narratief: }\end{array}$ & $\begin{array}{l}\text { Joh 1:1-18: Logos } \\
\text { word mens }\end{array}$ & $\begin{array}{l}\text { Joh } 20: 21-23: \text { Gees } \\
\text { toegesê aan dissipels }\end{array}$ \\
\hline Agtergrond: & $\begin{array}{l}\text { Ou Testament skeppings- } \\
\text { raamwerk: Gen 1:3 } \\
\text { רבקר אָלהיה }\end{array}$ & $\begin{array}{l}\text { Ou Testament skeppings- } \\
\text { raamwerk: Gen 1:2;2:7 } \\
\text { רוּחה }\end{array}$ \\
\hline $\begin{array}{l}\text { Affektiewe narrato- } \\
\text { logiese respons: }\end{array}$ & $\begin{array}{l}\text { Kenmerkend van } \\
\text { logos-sending is } \\
\text { nuwe lewe deur te glo } \\
\quad \text { (Joh } 1: 4 ; 20: 30 \text { ) }\end{array}$ & $\begin{array}{l}\text { Kenmerkend van } \\
\text { dissipelsending is } \\
\text { vergifnis van sondes } \\
\text { (Joh 20:23) }\end{array}$ \\
\hline
\end{tabular}

Alreeds in die Aanloop (1:1-51) van die narratief word die menswording van die Logos binne skeppingsperspektief vertel (1:1-18), asook die aanwysing van die dissipels $(1: 35-51)$. Dit beklemtoon die gemelde twee vertellyne.

Gedurende die Verloop van die vertelling (2:1-17:26) word die Goddelike skeppingsaktiwiteit geïllustreer deur die dade, tekens en woorde van die protagonis, die Seun. Jesus se openbare optrede maak God se creatio continua sigbaar. Hy bring die "nuwe skepping" in die "formaat" van die "nuwe lewe". Dit gaan oor "nuwe" wyn (2:1-12), -tempel (2:13-22), geboorte (3:1-21) en -water ( $4: 1-42)$, om slegs 'n paar voorbeelde te noem. Die "nuwe skepping" ontvou deur die sigbaarmaking van God die Skepper en Skeppingsagent se heerlikheid. Skepping word in die Johannese narratief gedra deur die 
van 'n geloofskeuse tussen die lig en die duisternis, tipiese skeppingsmotiewe. "Nuwe" sig bring geestelike insig (9:1-41). Die Skepper en Skeppingsagent is een in hul skeppingswerk (10:30). Dit word treffend geïllustreer deur die opwekking van Lasarus $(11 ; 1-44)$, sinspelend op die Seun se "uur" wat aanbreek (12:23). Aan die einde van hoofstuk 12 word die Skeppingsagent se sending saamgevat, dat $\mathrm{Hy}$ as die lig na die wêreld toe gekom het sodat die wat glo nie in die duisternis sou bly nie (12:46). Die twee storielyne kruis wanneer die dissipelsending in hoofstukke 13-17 prominent op die voorgrond tree. Die Parakleet-Gees sal die "nuwe skepping" verder voor deur die optrede van die dissipels (Joh 14:15-17, 25-26; 15:26-27; 16:4-11, 12-15).

In die Afloop van die Johannese narratief (18:1-21:25) word vertel dat die protagonis die hoogste prys betaal om die "nuwe skepping" se voortgang te waarborg. Sy opstanding manifesteer nog eens die skeppingsheerlikheid. Sy sterwenswoorde: "Dit is volbring" (19:30) plaas die seël op sy roemryke skeppingsoptrede. Die verskyningsverhale beklemtoon die "nuwe" begin, veral van die dissipelsending: Petrus is herstel (21:15-19); Maria Magdalena en die dissipels sien Hom (20:10-21:14) en Tomas kom tot "nuwe" insig (20:26-31). Die hoogtepunt van dié "nuwe" begin is sy toesegging van die Gees aan die dissipels (20:21-23). Dit word gedoen binne die raamwerk van die skeppingstradisie, as ons lees dat Jesus op die dissipels "geblaas" het (vgl Gen 2:7). Die vrug van die dissipelsending sal sigbaar word in die vergifnis van sonde (20:23). Die Johannese narratief eindig nie met ' $n$ vertelling van die protagonis se hemelvaart, soos in die ander evangelieverhale nie, maar met 'n bekragtiging van die dissipelsending.

\section{ENKELE GREPE UIT SKEPPINGSAGTERGRONDE}

Die vierde Evangelie moet binne die raamwerk van die Nabye Oosterse denke en tradisies gelees word. C H Dodd sê onomwonde: "The author of the Fourth Gospel also had Genesis before him, and the cast of his thought clearly suggests that he was acquainted, at least with Jewish thought proceeding on similar lines" (1965:41; Borgen 1965:3; Anderson 1984:124). Die bedoeling is nie om Nabye Oosterse skeppingsparallelle te soek met die oog op 'n moontlike interafhanklikheid nie, maar om slegs 'n breër verwysingsraamwerk van denke te formuleer. Die moontlike invloed van Nabye Oosterse en Semitiese opvattings sou eweneens nooit ontken kan word nie (Clifford 1994:17; Simkins 1994:26-31).

Die skeppingsverhale volgens Nabye Oosterse literatuur reflekteer dikwels 'n tendens van politeïsme en die stryd van gode om oorheersing. Dit staan in kontras met die Hebreeuse monoteïsme, hoofsaaklik aangebied in Genesis 1-11 (Anderson 1984:174). C Westermann onderskei veral vier skeppingstipes: skepping deur geboorte; skepping as resultaat van 'n stryd; 
skepping deur middel van die verdelings en laastens, skepping deur ' $n$ woord (Westermann 1984:26-41). Die Semitiese skeppingsverhale, asook die Johannese verwysings, is duidelike woord-skeppingsweergawes.

Die Sumeriese kosmogoniese tradisies is veral verbind met antieke stede en die eerste godheid wat daar gewoon het. Die stad Nippur speel daarom 'n belangrike rol. Die god Enki, god van die dieptes en wysheid, het die riviere swanger gemaak en die aarde bevrug om plante, diere en stede en konings voort te bring. Enki is versorg deur die godin Ninti wat "vrou van 'n rib" beteken (Lambert 1982:311-316). Dit herinner aan die Bybelse Eva. Enki het, volgens ' $n$ ander vertelling, mense van klei gemaak, met behulp van die godin Ninma. 'n Opvallende kenmerk van die Sumeriese skeppingsverhale is die erns waarmee dié verhale bejeën is omdat geglo is dat elke geskape persoon ' $n$ bestemming en plek van sy eie in die groot plan van die heelal het. Iemand se oorsprong is van kardinale belang. Volgens die Johannesevangelie is die mens se Godbepaalde oorsprong ook nie los te maak van sy uiteindelike bestemming nie (Van Dijk 1985; Heidel 1951:72-73). Dit betrek skepping en verlossing.

Die bekendste Akkadiese skeppingsverhaal word die enuma elish genoem waarvolgens die gode Tiamat ("die diepte") en Apsu ("soet water") bestaan. Na felle konflik onder die gode het Marduk vir Apsu doodgemaak en die mens van klei, vermeng met die bloed van die rebelgod Kingu, geskep. Die skeppergod kon eers skep nadat hy as die magtigste erken is (McKay 1962:269-273; Levenson 1988; Clifford 1992:1-15). In 'n ander verhaal, genaamd Atrahasis, vind ons 'n weergawe van die opstand. onder die gode, sowel as die verhaal van die groot vloed, na aanleiding van die mislukking van die geskape mens. Die noodsaaklikheid van straf en herstel na die mens se mislukking is ' $n$ veelseggende element as ons dit vergelyk met die Bybelse skeppingsverhale.

In die Egiptiese skeppingstradisies word beklemtoon dat die god Ptah geskep het deur sy gesaghebbende woord. Die klem op 'n skeppings-woord as skeppingsbeginsel leef in die Nabye Oosterse skeppingsliteratuur (Harnung 1983:172-184; Koch 1965:251-293; Allen 1988; Currid 1991:1840).

Van Kanaänitiese kant het ons die Ugaritiese tekste wat slegs verwysings bevat na godelyste. Deur seksuele voortplanting van veral die gode El en Ashera is die mensegeslag gebou. Skepping is ' $n$ daad van oorwinning (Clifford 1994:133; Green 1990:19-38). Die god Baäl is byvoorbeeld in 'n stryd gewikkel met die magte van die see. Dit herinner sterk aan JHWH se oorwinning oor die see, asook die prominensie van die oorwinningsmotief in die Johannesevangelie. 'n Mens sou kon praat van 'n tipiese Kanaänitiese patroon van chaos-oorwinning-terugkeer tot chaos-verlossing. Deutero-Jesaja vertel van 'n soortgelyke patroon (43:16-21). Om nie te 
praat van die tipiese Johannese verlossing uit die chaotiese en sondige (by wyse van interpretasie) duisternis na die lig van verlossing.'

Die tipiese Ou-Testamentiese voorbeeld van 'n skeppingsverhaal is opgeteken in Genesis 1-11. Dié kosmogonie volgens Genesis 1 is die weergawe van die Priesterdokument (P) wat waarskynlik later toegevoeg is aan die Jahwis-verhaal ( $\mathrm{J}$ ) as interpretasie vir Israel in die ballingskapsituasie (Westermann 1984; Anderson 1978:23-29; Von Rad 1984). Volgens die Genesis-weergawes skep God, die almagtige, deur sy skeppingswoord. Dit is ' $n$ daad van Goddelike mag en die gevolg is dat Skepper en skepsel in ' $n$ bepaalde verhouding geplaas is. Die transendensie van die Skepper teenoor die skepsel word deurgaans gehandhaaf. God se gesaghebbende skeppingswoord en -opdrag neem alle wind uit die seile van moontlike opvattings oor emanasie as skeppingsbeginsel.

Die Genesisverhaal (P-weergawe) begin by: "In die begin ..." (1:1). Die Skepper het reeds "in die begin" bestaan in eie reg, ten spyte daarvan dat chaos die oorheersende was. Uit die chaos skep God orde. Die "hemel en aarde" (1:1) behoort aan die Skepper omdat Hy dit geskape het. Dit verleen ook aan Hom 'n magsbasis met die oog op die verdere ontplooiing daarvan in die geskiedenis.

Op grond van God se skeppingsdade en sy magtige optrede in die geskiedenis, word sy volk Israel van tyd tot tyd opgeroep om op Hom te vertrou. Ná die sondeval deur die mens is die belofte gegee dat daar nooit weer só 'n oordeel oor die aarde uitgespreek sou word nie. Dit het egter aanleiding gegee tot die aartsvaderverhale, die eksodus en die bevrydende uittog in die "beloofde land". Die kontinuïteit tussen skepping en verlossing is ook in die P-weergawe van die skeppingsverhale merkbaar wanneer die vloedverhale vertel word. 'n Mens moet let op die tipiese patroon: chaos - skepping as ordening - mislukking deur die skepsel om aan die verwagtinge te voldoen - herstel na 'n ramp. Die erns van herskepping en herstel na die "gevalle" skepping is 'n belangrike element in die skeppingsverhale.

Só 'n herstel is binne verskillende teologiese raamwerke geplaas. In die tradisies is dit soms 'n "nuwe hemel" en 'n "nuwe aarde" genoem (Jes 66), 'n "nuwe skepping" of 'n "nuwe hart". Die bedoeling is om die oorspronklike skepping te herstel (Gen 1:30). Die vertelling in die vierde Evangelie verloop volgens ' $n$ soortgelyke patroon met die onderliggende skepping- en herskeppingsmotief prominent beklemtoond.

\footnotetext{
'In dic Apokricwe Johannes, 'n Gnostiese rë̈nterpretasie van die Bybelse skeppingsverhaal, vind ons soortgelyke patroon met 'n kinkel in die storie. Dit is die gode wat misluk omdat hulle jaloers is op die vooruitgang en meerdere kennis van die mens en nie die skepsele soos in ander soortgelyke verhale nie. Vergelyk C A Evans, Nag Hammadi Texts and the Bible. Leiden 1993, 472; G P Luttikhuizen, "Biblical Narrative in Gnostic Revision: The Story of Noah and the Flood in Classic Gnostic Mythology", in F G Martinez; G P Luttikhuizen (eds), Interpretations of the Flood. Leiden 1999, 109-123
} 


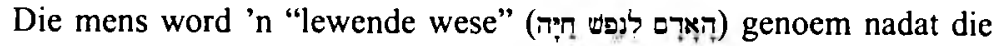

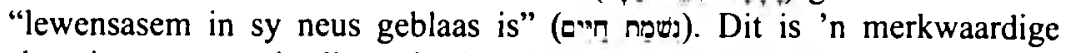
skeppingsmoment in die verhaal en kan as teologiese agtergrond dien vir Joh 20:22 waar Jesus oor die dissipels geblaas het en gesê het: "Ontvang die Heilige Gees" (NAV). Dat die mens na die "beeld" van God geskape is (Gen 1:26), beklemtoon dat die mens se bestemming, by wyse van interpretasie, ten nouste verband hou met sy oorsprong. Skepper en skepsel is verweef in 'n unieke verhouding sodat Johannes kan praat van "eiendom" en "eie" ( $(\delta\llcorner\circ)$ ! Volgens Bybelse skeppingsverhale is dit nie God wat misluk nie maar die mens as skepsel. Die noodsaaklikheid vir die herstel of verlossing van die "gevalle" mens is van die eerste bladsye van die Bybel af 'n wekroep wat volgens Joh 1 beantwoord word. 'n Mens sou teologies kon sê dat Johannes 1 en 20 die opvolghoofstukke is van Genesis 1 !

Die rol van God in die skepping word telkens besing in die Psalms $(77 ; 89 ; 96-99)$ en Deutero-Jesaja. Wat die huidige omstandighede ook al mag wees, die lesers word herinner aan God se groot skeppingsdade om daaruit geloof te put vir die huidige krisis (Albertz 1974:176; Kraus 1989:59-76; Fretheim 1988:16-30). Dieselfde denkskema kenmerk die Johannese vertelling. God se "nuwe skepping" deur die Logos word end-uit gevoer deur die "be-Geesterde" dissipelsending. Die kosmogonie het gefunksioneer soos 'n nasionale herdenkingsverhaal wat oor en oor vertel is met kragtige woorde vir elke geslag (Pss 93, 96, 114).

Volgens Jes 40-55 word God se skeppingswerk direk verbind aan sy verlossingswerk. G von Rad (1984:53-64) en R Rendtorff (1992:204-212) het dié verband onderbeklemtoon terwyl Westermann (1969:ad loc) en Clifford (1994:163-176), om enkeles te noem, deur definitiewe penstrepe Israel se verlossingstradisies ten sterkste verbind het aan die skeppingsverhale. Deutero-Jesaja het die fokus skerp geplaas op die element van die "nuwe" in God se verlossingspad met sy volk (40:12-31). Die verlossende eksodus-gebeure is skeppingsmatig en kosmies gesanksioneer. Die oorwinning oor die Farao is verbind aan die oeroorwinning toe die wêreld geskape is. Die "nuwe eksodus" is in 'n sekere sin 'n "nuwe" kosmogonie! Dit behels die terugkeer van die bannelinge vanaf Babilon na Sion toe! Die Johannes vertelling verhaal, by wyse van interpretasie, nog 'n "nuwe eksodus" wat as 'n "nuwe skepping" verstaan kan word, al kom die uitdrukking "nuwe skepping" nie by Johannes voor nie.

'n Groep kosmogonie-tekste in Deutero-Jesaja handel oor die bou van die tempel en tempelstad met die koning as agent van God. ${ }^{2}$ Dit word geïnterpreteer as skeppingshandelinge van God wanneer die volk terugkeer na Sion. Net soos die Skepper sy volk geskape het, só herskep hy hulle nou! Die bou van ' $n$ paleis, tempel of stad is gesien as metafore van die

${ }^{2}$ Vergelyk Jesaja 44:24-45:13; 45:14-25; asook Spr 3:19-20; 8:22-31 en Job 9:4-13; $10: 8-13 ; 12: 13-25 ; 25: 1-6 ; 26: 5-14 ; 36: 24-37: 24$. 
skeppingsdaad (Strack-Billerbeck I:733). Net só is die "opslaan van 'n tent" geïnterpreteer as 'n beeld van skepping (Foerster 1938:1015) in die Oosterse literatuur. Dit roep onmiddellik Johannes 1:14 in die herinne-ring

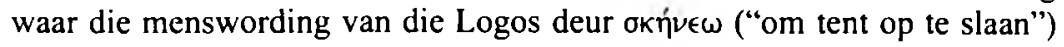
beskryf is.

In Rabbynse, apokriewe en pseudepigrafiese geskrifte val die fokus in skeppingsverhale baie sterk op skepping deur die Goddelike woord. ${ }^{3}$ Die wysheidswoord en skeppingswoord kulmineer in die hoogtepunt, volgens

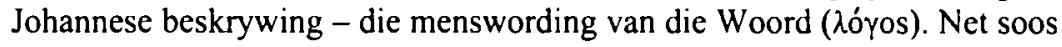
die Godswoord geskep het by die "eerste skepping", so skep God deur die Logos in die "nuwe skepping".

In die aansluiting by 'n interessante bekende Rabbynse uitdrukking dat God elke môre sy skeppingswerk hernu, merk Foerster treffend op: “... das Gott jeden Morgen "neu macht", zeigt dass er Tote erwecken wird oder dass er Israel erlösen wird" Foerster 1938:1018). God se vernuwende en verlossende krag lê in sy skeppingsmag. In tye van krisis en swaarkry het latere Judaïsme telkens teruggegryp na God as die Skepper deur sy skeppingswerke in herinnering te roep. Volgens die Tanaïtiese tradisie was die Tora die rede dat die wêreld geskape is (Carmichael 1996:32-40). Ongehoorsaamheid aan die Tora het vir Israel 'n ernstige oproep tot bekering beteken. Sommige pseudepigrafiese geskrifte praat van 'n "nuwe skepping" wat beteken dat die wêreld terugkeer na die volmaakte soos dit in die oertyd geheers het. Israel het ' $n$ groot behoefte gehad aan só 'n "nuwe skepping". ${ }^{4}$ Die Johannesevangelie sou op 'n besondere wyse die aanbreek van die "nuwe skepping" en die verder verloop daarvan vertel.

\section{TWEE FOKUSMOMENTE IN DIE SKEPPINGSELLIPS}

Vanuit skeppingsperspektief kan die narratief van die vierde Evangelie, soos reeds aangetoon, geïnterpreteer word as 'n "literêre" ellips, gefokus op twee skeppingsmomente: die menswording van die Logos en die toesegging van die Gees aan die dissipels. Slegs enkele hoogtepunte, rakende die skeppingsmotief, in dié twee momente word vervolgens genoem:

\subsection{Die eerste skeppingsmoment: menswording van die Logos (1:1-} 18)

Die proloog (1:1-18) funksioneer inhoudelik, by wyse van spreke, as overture of agenda van die vierde Evangelie. Die leser word teruggevoer tot voor die skepping, na die preëksistensie van die Logos. Sommige sien die

\footnotetext{
${ }^{3}$ Kyk Ep Ar, 139; Jdt 16:14; Wysheid van Salomo 9:1; 11:25; Bar 33; Jub 12:4; 4 Esr $3: 4 ; 6: 38$; S Bar $14: 17 ; 21: 4 ; 48: 2 ;$ Sib $3: 20$.

${ }^{4}$ Vergelyk 4 Esr 7:75; S Bar 32:6 (40:3); 44:12; 57:2; Jub 1:29; 4:26; 19:25; Apk Abr 17; Test L 4:1.
} 
proloog bloot as ' $n$ liniêre opeenvolging van gedagtes met die menswording van die Logos as die fokuspunt (Brown 1966:22; Barrett 1978:49-50; Beasley-Murray 1987:5). Selfs 'n literêre analise van die opvallende giasmes en parallelismes toon nie noodwendig dat die skeppingsmotief die sentrale plek in die struktuur beklee nie (Boismard 1957; Culpepper 1980:16; Staley 1988:50-57; Painter 1991:107-128). Culpepper meen dat vers $12 \mathrm{~b}$ die sentrale plek inneem op grond van sy aanname van 'n sogenaamde neerdaal/opvaar Christologie in die proloog: “... het Hy die reg gegee om kinders van God te word” (1980/81:17-18). Om egter vers 18 as verteenwoordigend van die opvaar-element te maak, soos Culpepper, is

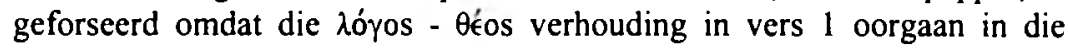
Seun-Vader verhouding om die historiese menswording te beklemtoon. Sentrale skeppingselemente in die proloog word verteenwoordig deur die klem op die "heerlikheid" ( $\left.\delta \delta^{\xi} \xi \alpha\right)$ van die mensgeworde Woord as "enigste by die Vader" (1:14). Let veral op die volgende elemente met skeppings-

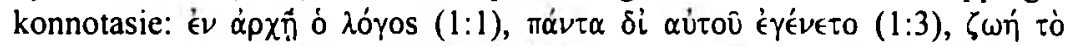

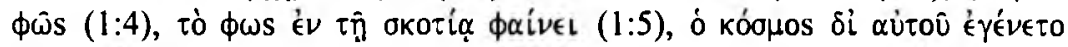

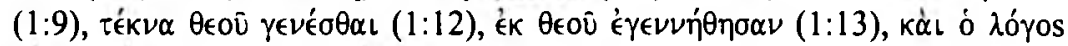

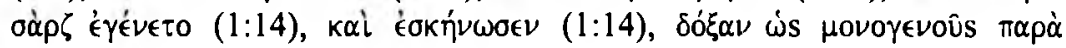

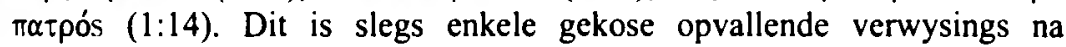
skepping, by wyse van interpretasie (Moloney 1993:25-27; Coloe 1997:4055; De la Potterie 1984:354-381).

$M$ Coloe se siening dat die ses skeppingsdae teruggevind word in ses strofes in die proloog is geforseerd maar open tog interessante perspektiewe (1997:46-49).

Vanuit die perspektief van die skeppingsmotief, kan die inhoud van die proloog soos volg ingedeel word:

Verse 1-5 Genesis van die "nuwe skepping"

Verse 6-8 Getuienis oor die "nuwe skepping"

Verse 9-13 Reaksie op die "nuwe skepping"

Verse 14-18 Verhoudinge in die "nuwe skepping"

\subsubsection{Genesis van die "nuwe skepping" (verse 1-5)}

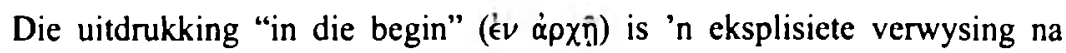
Genesis 1:1 (ב-2). Dit verwys na die Logos se bestaan voor die skepping reeds (Brown 1966:4) in 'n kwalitatiewe sin en nie in 'n temporele betekenis nie.

Die herhaalde gebruik van "die Woord" (o $\lambda o_{\gamma}$ os) in verse 1 en 2 is merkwaardig. Die drievoudige herhaling beklemtoon die preëksistensie van die Logos: "In die begin was die Woord daar"; tweedens: “... en die Woord was by God" en derdens: "en die Woord was self God" (1:1). 'n Mens sou, by wyse van interpretasie, kon sê dat die beliggaming van die "nuwe skepping" in die Logos, reeds bestaan het voor die "eerste" skepping! Die 
gebruik van Logos ( $\lambda$ óyos) kan beïnvloed wees deur die Hellenisties Gnos-

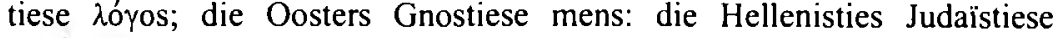

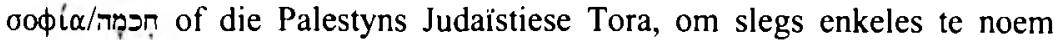
(Strack-Billerbeck II:333-352; Brown 1966:4-5). Die moontlike agtergrond van die Aramese מימרא sou ook bygevoeg kon word (Strack-Billerbeck II:341-348). Die P-weergawe van die skeppingsverhale beklemtoon uitdruklik die rol van die Goddelike Woord in die skeppingshandelinge (יאמר אלהים). Die Akkadiese nadruk op die krag van die woord word ook in gedagte gehou. Dit is egter die personifiëring van die Judaïstiese Wysheid deur middel van die Tora wat waarskynlik die moontlike agtergrond verleen (Wysheid 7:22-8:1). Die "woord van die Here" het volgens die Johannesevangelie op 'n nuwe ekspedisie, die "nuwe skepping, vertrek met die oog op die verlossing van die mens.

Die uitdrukking in 1:3: "Alles het deur Hom tot stand gekom ..."

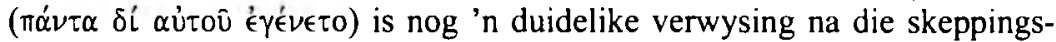

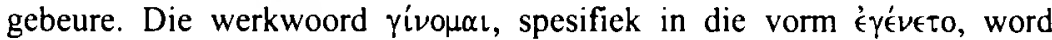
konstant gebruik in die LXX van Genesis 1 om skepping mee uit te druk (Brown 1966:6). Die Logos is die Skepper-Agent in universele sin maar ook die eskatologiese Openbaarder in die "nuwe skepping".

Die Logos gee aan die geskape mensheid die volheid van lig en lewe. Lewe definieer die basiese bestaan en lig is 'n nadere bepaling. In verskillende Judaïstiese bronne is Wysheid en die Tora geassosieer met lewe en lig (Strack-Billerbeck 11:356-358; Schnackenburg 1968:240-242). Volgens Gen 2:7 het die Here God "lewensasem" in die mens se neus geblaas en in Gen 1:3 sê God: "Laat daar lig wees". Die skeppingsmatige lewe en lig word in die Johannese vertelling in verband gebring met die verlossingsbekendmaking deur die Logos: lewe word verbind aan opstanding of ' $n$ geestelike bestaan en lig dien as metafoor vir die openbaring wat verlossing bring. Net soos lig die aanvanklike chaos/duisternis (by wyse van interpretasie) georden het, só oorweldig die lig van verlossing die duisternis van sonde en verwerping (Van der Watt 1998:29-78). Die vergeesteliking van die geskape lig en lewe benadruk die Johannese eie gerigtheid om in sy gedagtegang te beweeg vanaf die letterlike skeppingsmatige tot die eskatologiese verlossingsmatige. Die terminologiese en teologiese onderbou van die skeppingsmotief gee drakrag aan die Johannese narratief.

\subsubsection{Getuienis oor die "nuwe skepping" (verse 6-8)}

In kontras met die werkwoord iv ("was") wat gebruik is om die Logos se preëksistente bestaan mee te beskryf, word Johannes die Doper se histo-

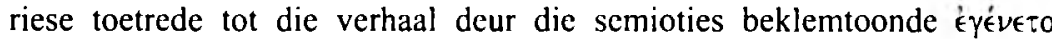
gedoen (1:6). Dit verhaal die inleiding tot die historiese werk van die Logos op aarde. Johannes die Doper vervul 'n brugfunksie in die narratief: die oorgang vanaf skepping tot "nuwe skepping", geopenbaar deur die Logos. Hy beklemtoon die hooffunksie van die Logos, om as lig mense te verlos. 
Deur teologisering wend die vierde Evangelie die kosmiese skepping aan om die uiteindelike doel van universele verlossing 'n grondige basis te gee. Dit handel oor veel meer as net die gebruik van skeppingsverhaalterme.

\subsubsection{Reaksie op die "nuwe skepping" (verse 9-13)}

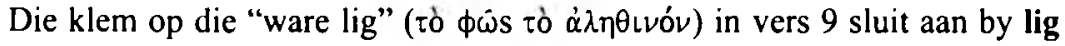

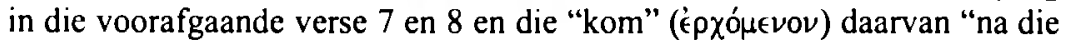
wêreld toe" (1:9) berei die leser voor vir die beslissingsmoment volgens vers 10 . Die verligting van die mensheid is 'n tipiese Messiaanse uitdrukking (Jes 9:2; 42:6; 60:1-2) om verlossing mee uit te druk. Die funksies van die Wysheid en Tora is oorgedra op die Logos. Die Logos as "ware lig" is God se verlossingsbetrokkenheid in hierdie wêreld as oogmerk van die "nuwe skepping".

Die uitdrukking "die wêreld het deur Hom tot stand gekom" (1:10) verwys na die oorgang vanaf skepping tot die historiese wording van die mensheid. Die terme "wêreld" of "geskape orde"(kóouos) en "tot stand

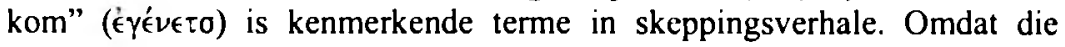
mensheid as deel van die "geskape orde" ontaard en misluk het, ${ }^{\mathrm{s}}$ die Logos die "nuwe skepping" ingelui.

Die Skepper het reg op sy skepping. Daarom word gepraat van sy

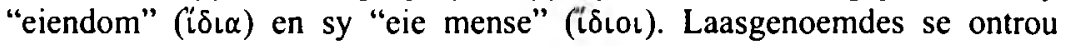
teenoor hul Skepper het die Herskepper se trou deur die "nuwe skepping" in werking te stel (Schnackenburg 1968:259; Brown 1966:29-30; Pollard 1958:148; Barrett 1955:132).

Die agenda vir die res van die "nuwe skepping" word gestel in 1:12: Sommige het Hom "aangeneem" en andere het Hom verwerp. Diegene wat glo, het as skepsels van God "nuwe skepsels", dit is "kinders van God", geword. Natuurlike geboorte (skepping) maak iemand nie 'n kind van God

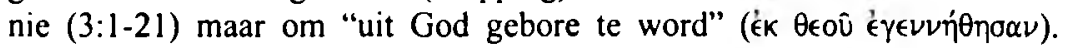
Drie uitdrukkings kontrasteer die "natuurlike" of "eerste" skepping met die spirituele "nuwe skepping": "nie van nature nie"; "nie deur die drang van 'n mens", en "of die besluit van 'n man nie". Die "nuwe skepping" "van bo" ( $\alpha \nu \omega \theta \in \nu)$ kan ook die spirituele skepping volgens Johannes genoem word $(3: 6,8)$.

\subsubsection{Verhoudinge in die "nuwe skepping" (vss 14-18)}

Die historiese hoogtepunt vind plaas wanneer die preëksistente Logos

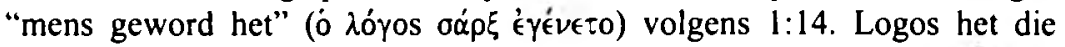
aardse en stoflike betree. Die oorgang vanaf die preëksistente "was" (iv) na

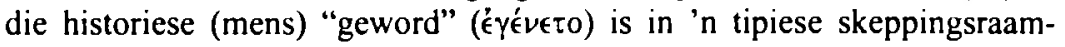
werk vertel.

\footnotetext{
5 Vergelyk die oorwegend negatiewe betekenisgebruik van ó kóouos in die Johannese narratief: $1: 10 ; 7: 7 ; 14: 17,22,27,30 ; 15: 18-19 ; 16: 8,20,33 ; 17: 6,9,14$.
} 


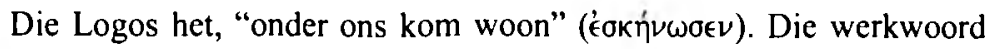

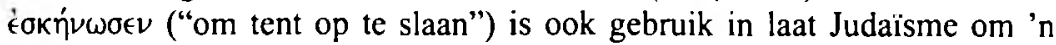
skeppingsdaad mee te beskryf (Foerster TWNT III:1015). Die historiese verwerkliking van die "nuwe skepping" word deur tipiese skeppingsterme

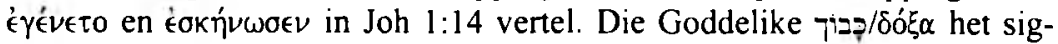
baar geword. Net soos die heerlikheid van God die plek van ontmoeting gevul het, só is die heerlikheid van die Here sigbaar in die menswording van die Logos as manifestasie van die "nuwe skepping". Dit kan slegs

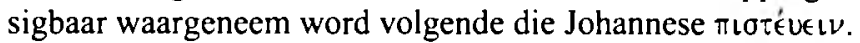

Die Skepper se אמר net sigbaar geword by Sinaï, in die tabernakel en nou, in die "nuwe tabernakel", die Logos. Die Seun maak God se genade en waarheid sigbaar bekend (1:14). Die Seun is die "enigste"

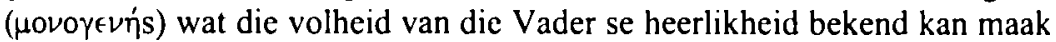
(1:14). Net soos die heerlikheid van JHWH sigbaar geword het in die tent van samekoms (אהל מועך), só gaan God se sigbare skeppingswerke voort in die "nuwe skepping" (Eks 33:22; Deut 5:22).

Moses en die wet (ó vónos), verteenwoordigend van die "eerste skepping", word oortref deur die "genade en waarheid" (1:17) van die "nuwe skepping", beliggaam in Jesus Christus. Die verbintenis tussen Tora ("wet") en skepping is welbekend in laat Judaïsme. Die proloog (1:1-18) reik vanaf die "eerste skepping", waar God en die Logos opgetree het, tot by die verwerkliking van die "nuwe skepping" wanneer Vader en Seun die verlossing van die mens in skeppingsterme tot uitvoer bring.

\subsection{Die tweede skeppingsmoment: toesegging van die Gees (20:21- 23)}

Vanuit die skeppingsperspektief gelees, is die toesegging van die Gees aan die dissipels 'n fokusmoment in die Johannese narratief (20:21). Enkele voorafgaande geselekteerde insidente en momente toon dat die Skeppingsagent die "nuwe skepping" sigbaar laat deurbreek in sy woorde, "tekens" en optredes voordat Hy die mandaat deurgee aan sy dissipels.

Simbolies geïnterpreteer, word die water as verteenwoordigend van die "eerste skepping" verplaas deur wyn, simbolies van die "nuwe skepping" (2:1-11). Net só word fisiese siekte, blindheid en dood vervang deur die "nuwe skepping" se lewegewende gesondheid en nuwe lewe wat die fisiese en geestelike omspan (9:1-41;11:1-43). Die Gees werk nie net mee aan die totstandkoming van fisiese lewe nie (Gen $1: 2 ; 2: 7$ ), maar ook by die geestelike geboorte "van bo" (3:1-21). Die teenstelling tussen "gebore uit water" en "gebore uit Gees" (3:5) illustreer die onderliggende teologiese beklemtoning van die verskuiwing vanaf die "eerste skepping" na die "nuwe skepping". Dieselfde kan gesê word van die "lewende water" wat aan iemand die ewige lewe gee (4:14). Die protagonis Jesus is deurgaans

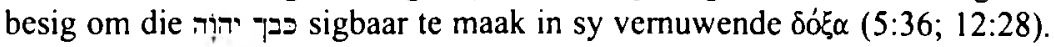


Die manna wat Moses gee, bied tydelike versadiging maar "die brood wat lewe gee" voed iemand vir die ewige lewe (6:35).

Die skeppingsheerlikheid ( $\left.{ }^{-}{ }^{-}\right)$word sigbaar in 'n verlossingsheerlikheid $(\delta o ́ \xi \alpha)$ wat deur die Seun en sy dissipels in 'n "nuwe" skeppingsprogram verder gevoer word. Dié program se uitvoerbaarheid berus op die getuienis van die Gees (14:16). Die uitvloeisel hiervan is Jesus se toesegging van die Gees aan sy dissipels. Hulle is byeen wanneer die Seun van God oor hulle blaas en sê: "Ontvang die Heilige Gees" (20:22).

Die effektiewe voortgang van die "nuwe skepping" het 'n diep drif binne-gegaan na Jesus se dood. Die dissipels verkeer agter geslote deure uit vrees vir die Joodse leiers wat tiperend is van die aanslag van die "duisternis" teen die "lig". Die beklemtoning van die dissipels se fisiese waarnem-

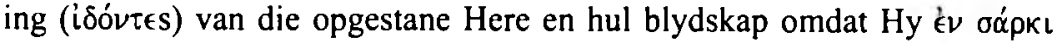
voor hulle verskyn, word vertel in die raamwerk van die menswording van die Logos (1:1-18; 1 Joh 1:1-4). Dit is 'n heropvoering van die inkamasie.

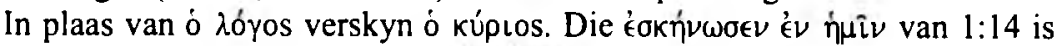

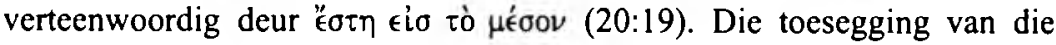
Gees as skeppingsmoment word vertel in die raamwerk van sending. Net soos die Skeppingsagent deur die Skepper gestuur is om die "nuwe skepping" te vestig, só word die dissipels teruggestuur na die wêreld toe om die "nuwe skepping" te proklameer (20:21). Die Skepper het die Gees oor sy Agent uitgegiet sonder maat (Joh 1:32; 3:34; 4:34; 5:19; 6:27; 10:36; 17:4).

Die Skepper se "blaas van lewensasem in die neus van die mens" (Gen 2:7) word herhaal wanneer Jesus oor sy dissipels blaas (20:22). Binne 'n skeppingsraamwerk gelees, borg die Skepper en Skeppingsagent die voortgang van die skepping as sigbare daad van God se betrokkenheid by. sy wêreld. Die simboliese "blaas" (Gen 2:7; Joh 20:22) is 'n metafoor om die oordrag van lewe mee voor te stel. ${ }^{\circ}$ RE Brown toon aan dat volgens Nabye Oosterse geloof die asem van 'n heilige of hoogaangeskrewe persoon "... has supernatural power to heal or to immobilize a person" (1972:1023).

Die parallel met die blaas van die lewensasem in Adam (Gen 2:7) is opvallend. Alhoewel die LXX die term mvoń gebruik was dit tog moontlik

\footnotetext{
${ }^{6}$ Die werkwoord $\dot{\epsilon} \mu \phi u \alpha \dot{\alpha} \omega$ kom slegs in Joh 20:22 in die Nuwe Testament voor. Die verbintenis met die oordrag van die "gees van lewe" kom elf keer voor in die LXX, onder andere in Genesis 2:7; 1 Konings 17:21; Esegiël 37:9; Wysheid 15:11. Kyk G

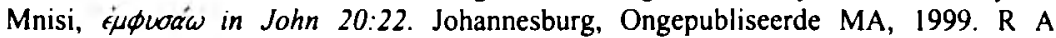
Culpepper, Anatomy, 107 beweer dat die "... breathing re-enacts the primordial image of the creation of man". Vergelyk verder R E Brown, Gospel II, 1022; R Schnackenburg, Gospel III, 324-326.
} 
dat die vierde Evangelie 'n vorm kon geken het wat $\pi v \in \hat{v} \mu \alpha$ bevat.' Die Ou Testamentiese רוח (Gen 1:2) is bewys van God se skeppende teenwoordigheid en optrede (Baumgartel TWNT VI:346-366; Vos 1985:70-89). God self plaas die חרוn in die hart van sy volk (Jes 63:11). Op so 'n wyse sit God sy herskeppingswerk voort deur die "nuwe" en verlossing te bewerk vir sy volk deur die Gees (Eseg 11:19; 18:31; 36:26). Die verband tussen God se skeppings-Gees (רוח) en skeppingswoord (רכר) wat albei prominent by die "eerste skepping" funksioneer, is ook kenbaar in die "nuwe skepping" wanneer die mensgeworde Logos, Woord van God en self ook God, die Goddelike woord spreek en oor die dissipels blaas, simbolies van die toesegging van die Gees.

Deur sy Gees het God mense toegerus vir hul taak. Dawid, om slegs 'n enkele voorbeeld te noem, ontvang die Gees wanneer hy deur Samuel gesalf is (1 Sam 16:13). Net só, volgens die LXX, sal God sy verkorenes toerus met die Gees wanneer Hy die eskatologiese Gees op hulle sal uitstort (Jes 44:3; Eseg 11:19; Joel 2:28). Volgens die apokriewe, pseudopigrafiese en Rabbynse literatuur sal die Messias wat verwag is oor die Gees van God beskik gedurende die sogenaamde eindtyd (Sjöberg TWNT VI:384). Die belofte van vernuwing is aan die Gees van God verbind in al die verwagtinge. Die Gees was God se skeppingsinstrument, by wyse van spreke. Die gawe van die Gees is ook verbind aan die vergifnis van sonde, net soos in Johannes 20:23 (Eseg 36:25-27; I QS 4:20; Hand 2:38).

Vanuit 'n skeppingsmotief gelees, voldoen die toesegging van die Gees volgens Johannes 20:2l-23 aan die dissipels aan al die verwagtinge. Die tweede fokusmoment in die skeppingsellips (20:21-23) borg die Skepper se toekoms op aarde. Dit rond die eerste moment $(1: 1-18)$ af en vorm saam 'n heropvoering van die drama van Genesis 1-11. Die element van vernuwing en verlossing is toegevoeg omdat die mens misluk het na die "eerste skepping". Die teologiese skeppingsmotief open by die lees van die vierde Evangelie nuwe perspektiewe.

\section{Literatuurverwysings}

Albertz, R 1974. Weltschöpfung und Menschenschöpfung: Untersuch bei DeuteroJesaja. Hiob und in den Psalmen. Stuttgart: Kohlhammer.

Allen, J P 1988. Genesis in Egypt. New Haven: Yale University Press.

Anderson, B W 1978. "From Analysis to Synthesis: The Interpretation of Gen 1-11", $J B L$ 97, 23-29.

Anderson, B W 1984. "Mythopoeic and theological Dimensions of Biblical Faith", in B W Anderson (ed), Creation in the Old Testament. Philadelphia: Fortress, 1-24.

Bartett, C K 1976 (1955). The Gospel according to St John. London: SPCK.

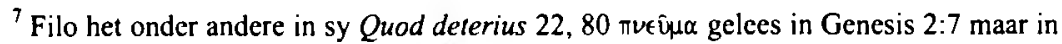
Legum allegoria 1, 13,42 weer mvon gelees. Die indruk is gewek dat soms rvoń gelees is maar dat dit geïnterpreteer is as $\pi v \in \hat{u} \mu \alpha$.
} 


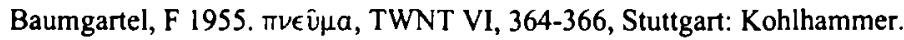

Beasley-Murray, G R 1987. John. Waco: Word Books.

Boismard, M-E 1957. St John's Prologue. London: Mowbrey.

Borgen, P 1965. Bread from Heaven: An Exegetical Study of the Concept of Manna in the Gospel of John and the Writings of Philo. Leiden: Brill.

Brown, R E 1966. The Goespel according to John. Vol I. London: Chapman.

Brown, R E 1972. The Gospel according to John, Vol II. London: Chapman.

Carmichael, C M 1996. The Story of Creation. Its Origin and its Interpretation in Philo and the Fourth Gospel. London: Academic Press.

Clifford, R J 1994. Creation Accounts in the Ancient Near East and in the Bible. Washington: CBA.

Clifford, R; Collins, J J 1992. "The Theology of Creation Traditions", in Creation and Biblical Traditions. Washington: CBA, 1-15.

Coloe, M 1997. "The Structure of the Johannine Prologue and Genesis 1", Austr Bibl $\operatorname{Rev} 45,40-55$.

Culpepper, R A 1980/81. "The Pivot of John's Prologue", NTS 27, 1-31.

Culpepper, R A 1983. Anatomy of the Fourth Gospel. A Study in Literary Design. Philadelphia: Fortress.

Currid, J D 1991. "An Examination of the Egyptian Background of the Genesis Cosmogony", $B Z 35,18-40$.

Darr, J A 1993. "Narrator as Character: Mapping a Reader-Oriented Approach to Narration in Luke Acts", Semeia 63, 47.

De la Potterie, I 1984. "Structure du Prologue de Saint Jean", NTS 30, 354-381.

Du Rand, J A 1986. Plot and point of view in the Gospel of John, in Petzer, J H; Hartin, P J (eds) A South African perspective on the New Testament: Festschrift BM Metzger. Leiden: Brill, 149-169.

Du Rand, J A 1998. "Reading the Fourth Gospel like a literary symphony", in F F Segovia (ed) What is John: Literary and Social readings of the Fourth Gospel, Atlanta: Scholars press, 5-18.

Dodd, C H 1965. The interpretation of the Fourth Gospel. Cambridge: CUP.

Evans, C A 1993. Nag Hammadi Texts and the Bible. Leiden: Brill.

Foerster, W 1938. $\kappa$ Ti $\xi \omega$, TWNT III, Stuttgart: Kohlhammer, 999-1034.

Fretheim, T E 1988. "Nature's Praise of God in the Psalms", Ex Auditu 3, 16-30.

Green, G 1990. "Myth, History and Imagination: The Creation in Bible and theology", Horizons in Biblical Theology 12, 19-38.

Harnung, E 1983. Conceptions of God in Ancient Egypt (trans! J Baines). London: Black.

Heidel, A 1951. The Babylonian Genesis. Chicago: Univerity Press.

Koch, K 1965. "Wort und Einheit des Schöpfergottes in Mephis und Jerusalem", ZTK 62, 251-293.

Kraus, H J 1989. Theology of the Psalms. Minneapolis: Fortress.

Lambert, W G 1982. "The Interchange of Ideas between Southern Mesopotamia and Syria-Palestine as seen in Literature", in H J Nissen; J Renger (eds), Mesopotamien und seine Nachbarn. Berlin: De Gruyter. 
Levenson, J D 1988. Creation and the Persistence of Evil: The Jewish Drama of Divine Omnipotence. San Francisco: Harper Collins.

Luttikhuizen, G P 1999. "Biblical Narrative in Gnostic Revision: The Story of Noah and the Flood in Classic Gnostic Mythology", in F G Martinez; G P Luttikhuizen (eds), Interpretations of the Flood. Leiden: Brill, 109-123.

McKay, K L 1962. "Creation", in J D Douglas e a, The New Dictionary. London: IVF, 269-273.

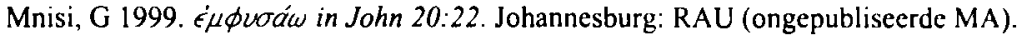

Moloney, F 1993. Belief in the Word: Reading John 1-4. Minneapolis: Fortress.

Moore, S D 1989. “Doing Gospel Criticism as/with a Reader", BThB 19, 85-92.

Painter, J 1991. The Quest for the Messiah. The History', Literature and Theology of the Johannine Community. Edinburgh: T and T Clark.

Pollard, T E 1958. "Cosmology and the Prologue of the Fourth Gospel", Vigchr 12, 147-153.

Rendorff, R 1992. "Some reflections on creation as a topic of Old Testament theology", in Ulrich, E (ed), Priests, Prophets and Scribes: Essays on the formation and heritage of second temple Judaism: Festschrift J Blinkinsopp. Sheffield: Almond, 204-212.

Rissi, M 1983. "Der Aufbau des vierten Evangeliums", NTS 29, 48-54.

Rotz, C 1992. Narrative Strategies in the Communication of the Gospel: John 4:I-42, A Case Study, Port Elizabeth (ongepubliseerde MA-verhandeling).

Schnackenburg, R 1968. The Gospel according to St John, Vol 1. Trs. K Smyth. London: Burns and Oats.

Schnackenburg, R 1982. The Gospel according to St John, Vol Ill. Trs. D Smith. London: Bums and Oats.

Simkins, R A 1994. Creator and Creation. Nature in the Worldview of Ancient Israel. London: Routledge.

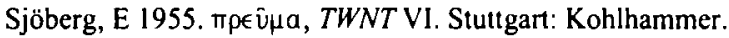

Staley, J L 1988. The Print's First Kiss: A Rhetorical Investigation of the Implied Reader in the Fourth Gospel. Atlanta: Scholars Press.

Strack, H L; Billerbeck, P 1924. Das Evangelium nach Markus, Lukas unde Johannes unde die Apostelgeschichte aus Talmud und Midrash. München: Beck.

Tannehill, R C 1980. "The Gospel of Mark as Narrative Christology", Semeia 16, 57. 95.

Van der Watt, J G 1998. "The dynamics of metaphor in the Gospel of John", SNTU 23, 29-78.

Van der Watt J G 1991. "Die Woord het Mens geword: 'n Strukturele uiteensetting van die teologie van die Johannesevangelie", in J H Roberts, W S Vorster, J N Vorster en $\mathrm{J} \mathrm{G}$ van der Watt (reds), Teologie in konteks (Feesbundel A B du Toit), Midrand: Orion, 93-103.

Van Dijk, J e a, 1951. Early Mesopotamian Incantations and Rituals. New Haven: Yale University Press 1985. 
Von Rad, G 1984 (1936). "The Theological Problem of the Old Testament Doctrine of Creation", in Anderson, B W (ed), Creation in the Old Testament. Philadelphia: Fortress.

Vos, C J A 1985. "'n Uitsig vanuit die kosmiese werk van die rûah op die Pneumatologie", Skrif en Kerk 6, 70-89.

Westermann, C 1984. Genesis 1-11: A Commentary. Minneapolis: Fortress.

Westermann, C 1969. Isaiah 40-66. Philadelphia: Fortress. 